\title{
Transforming growth factor- $\beta 1$ upregulates the expression of CXC chemokine receptor 4 (CXCR4) in human breast cancer MCF-7 cells
}

\author{
Xiao-ping ZHAO ${ }^{1, \# \text {, Yong-yao HUANG, \#, Yu HUANG }}{ }^{1}$, Ping $\mathrm{LEI}^{1}$, Ji-lin PENG ${ }^{1}$, Sha WU ${ }^{1}$, Min WANG ${ }^{1}$, Wen-han $\mathrm{LI}^{1}$, Hui-fen
} $\mathrm{ZHU}^{1}$, Guan-xin SHEN ${ }^{1, *}$

${ }^{1}$ Department of Immunology, Tongji Medical College, Huazhong University of Science and Technology, Wuhan 430030, China; ${ }^{2}$ Department of Surgery, Hubei Hospital of Traditional Chinese Medicine, Wuhan 430074, China

Aim: To investigate whether rhTGF- $\beta 1$ or a recombinant vector encoding a fusion protein comprising an extracellular domain of TGF- $\beta$ receptor II and an IgG FC fragment) affects the regulation of CXC chemokine receptor 4 (CXCR4) expression in MCF-7 human breast cancer cells.

Methods: MCF- 7 breast cancer cells were treated with rhTGF- $\beta 1$ or transfected with a recombinant vector, pIRES2-EGFP-T $\beta R I I-F C$. Expression of CXCR4 in these cells was then analyzed at the mRNA and protein levels by quantitative RT-PCR and flow cytometry assay, respectively. A transwell assay was used to measure the chemotactic response of these cells to SDF-1 $\alpha$.

Results: CXCR4 mRNA and protein expression were upregulated in TGF- $\beta 1$-treated MCF-7 cells. These cells also demonstrated an enhanced chemotactic response to SDF-1 $\alpha$. In MCF-7 cells transiently transfected with pIRES2-EGFP-TßRIII-Fc, a fusion protein named TBRII-Fc (approximately $41 \mathrm{kDa}$ ) was produced and secreted. In these transfected cells, there was a reduction in CXCR4 expression and in the SDF-1 $\alpha$-mediated chemotactic response.

Conclusion: TGF- $\beta 1$ upregulated CXCR4 expression in MCF-7 cells, which subsequently enhanced the SDF-1 $\alpha$-induced chemotactic response. The results suggest a link between TGF- $\beta 1$ and CXCR4 expression in MCF-7 human breast cancer cells, which may be one of the mechanisms of TGF- $\beta 1$-mediated enhancement of metastatic potential in breast cancer cells.

Keywords: transforming growth factor- $\beta 1$; CXC chemokine receptor 4; stromal cell-derived growth factor-1 $\alpha$; breast cancer; metastasis

Acta Pharmacologica Sinica (2010) 31: 347-354; doi: 10.1038/aps.2009.204; published online 15 February 2010

\section{Introduction}

Breast cancer is one of the most common forms of malignancy in women around the world. Moreover, metastatic cancer is the main cause of death for breast cancer patients. Although the precise mechanism remains unclear, both transforming growth factor beta 1 (TGF- $\beta 1$ ) and CXC chemokine receptor 4 (CXCR4) may play important roles in the process of breast cancer metastasis ${ }^{[1,2]}$.

CXCR4 is a seven-transmembrane $G$ protein-coupled receptor. A ligand for this receptor is stromal cell-derived growth factor-1a (SDF-1a or CXCL12), which is a member of the CXC chemokine family ${ }^{[3,4]}$. The SDF-1a/CXCR4 interaction is critical for the migration of hematopoietic and non-hematopoietic cells in physiological and pathological processes ${ }^{[5]}$. Muller

\footnotetext{
\# The first two authors contributed equally to this work.

* To whom correspondence should be addressed.

E-mail guanxin_shen@yahoo.com.cn (Guan-xin SHEN).

Received 2009-09-01 Accepted 2009-12-28
}

et al demonstrated that CXCR4 expression was upregulated in human breast cancer cells, malignant breast tumors and metastases, but was undetectable in normal mammary epithelial cells ${ }^{[2]}$. SDF-1 $\alpha$ is constitutively produced in many organs and is especially abundant in the bone marrow, lymph nodes, lungs and liver ${ }^{[2,6]}$. The SDF-1a/CXCR4 interaction contributes to the metastatic spread of breast cancer cells to these organs, which are the main sites of human breast cancer metastases ${ }^{[2]}$.

TGF- $\beta 1$ has also been suggested to play a critical role in breast cancer metastasis ${ }^{[7]}$. In fact, TGF- $\beta 1$ is a multifunctional cytokine that elicits a diverse range of cellular responses including cell proliferation, differentiation, apoptosis, matrix remodeling, adhesion, invasion and migration ${ }^{[8]}$. Generally, TGF- $\beta 1$ can be produced by many different cell types and is usually secreted in a latent (ie inactive) form, which is unable to bind to its receptors until converted to its active form $^{[1]}$. Once activated, TGF- $\beta 1$ binds to TGF- $\beta$ type II receptor (T $\beta R I I)$, which then recruits, phosphorylates and activates TGF- $\beta$ type I receptor (T $\beta R I)$, and signal transmission is finally 
initiated $^{[1]}$. Intriguingly, TGF- $\beta 1$ expression was increased significantly in advanced human breast tumor cells ${ }^{[9-11]}$. More importantly, there is growing evidence that indicates aberrant TGF- $\beta$ expression is associated with breast cancer metastasis ${ }^{[7]}$. For example, increased TGF- $\beta 1$ expression resulted in the promotion of breast cancer metastasis ${ }^{[12]}$, while blockade of TGF- $\beta$ signaling has been shown to inhibit breast cancer metastasis $^{[13-16]}$.

Previous studies have investigated the relationship between TGF- $\beta 1$ and CXCR4 expression. For example, TGF- $\beta 1$ has been reported to induce the expression of CXCR4 on dendritic cells $^{[17,18]}$. Similar results were also observed in eosinophils, $\mathrm{CD}^{+} \mathrm{T}$ cells , macrophages derived from monocytes ${ }^{[19-21]}$, and so on. Moreover, Javelaud et al found that TGF- $\beta 1$ upregulated CXCR4 mRNA expression in melanoma cells ${ }^{[22]}$.

As there were few studies available, we wanted to investigate the effect of TGF- $\beta 1$ on the regulation of CXCR4 expression in MCF-7 breast cancer cells, which have been reported to express CXCR4, TGF- $\beta 1$ and its receptors ${ }^{[2,23,24]}$. In this study, we applied two strategies. In one strategy, MCF-7 cells were treated with TGF- $\beta 1$, and the other strategy involved transient transfection of MCF-7 cells with a recombinant vector encoding a fusion protein comprising the extracellular domain of TGF- $\beta$ receptor II and an IgG FC fragment. We then examined the expression of CXCR4 in these cells and their chemotactic response to SDF-1a.

\section{Materials and methods} Mammalian cell culture

Human breast cancer cell line MCF-7 was maintained in DMEM containing 10\% fetal bovine serum (FBS), $100 \mathrm{U} / \mathrm{mL}$ penicillin, and $100 \mathrm{mg} / \mathrm{mL}$ streptomycin and incubated at $37^{\circ} \mathrm{C}$ in a $5 \% \mathrm{CO}_{2}$ atmosphere.

\section{TGF- $\beta 1$ treatment}

MCF-7 cells were seeded into 24-well plates in DMEM with $10 \%$ FBS and cultured for $24 \mathrm{~h}$. The cells were washed with PBS and then treated with various concentrations $(0,1,10,100$ $\mathrm{ng} / \mathrm{mL}$ ) of rhTGF- $\beta 1$ (Upstate) in serum-free DMEM for $48 \mathrm{~h}$ before harvesting.

\section{Construction and transient transfection of bicistronic vectors}

The extracellular region of the human TGF- $\beta$ type II receptor was amplified by PCR from $\mathrm{pEGFP} / \triangle \mathrm{T} \beta \mathrm{RII}$ constructed previously ${ }^{[25]}$ and introduced 5' BamH I and 3' Hind III restriction sites. The PCR products were then purified, digested with BamH I and Hind III, and inserted into a recombinant vector pcDNA3.1-Fc ${ }^{[26]}$ containing the Fc fragment of human IgG1. Next, the chimeric gene of TGF- $\beta$ receptor II and IgG FC fragment (T $\beta$ RII-Fc) was subcloned into the $B g l$ II/Sal I sites of the pIRES2-EGFP vector to generate a recombinant plasmid pIRES2-EGFP-T $\beta$ RII-Fc. Their authenticity was confirmed by DNA sequencing.

The recombinant vector pIRES2-EGFP-T $\beta$ RII-Fc was transfected into MCF-7 cells using the lipofectamine method described previously ${ }^{[27]}$, while control cells were transfected with the vector pIRES2-EGFP.

\section{Reverse transcription-PCR}

To examine T $\beta$ RII-Fc mRNA expression in MCF-7 cells transfected with pIRES2-EGFP-T $\beta$ RII-Fc, RT-PCR assay was performed as described previously ${ }^{[27]}$. The sequences of the primers were as follows: sense primer: 5'-GGAAGATCTACCATGGGTCGGGGGCTGCTC-3' and antisense primer: 5'-ACGCGT CGACTCATTTACCCGGGGACAG-3'. Finally, the PCR products were analyzed on $1.5 \%$ agarose gel electrophoresis.

\section{Western blotting analysis}

Cell lysates of the transfected cells or parental MCF-7 cells were prepared, separated by SDS/PAGE, blotted onto a PVDF membrane as described previously ${ }^{[27]}$, and then probed with horseradish peroxidase (HRP)-conjugated goat anti-human IgG (Pierce) to detect recombinant protein T $\beta$ RII-Fc expression. After cells were washed with PBST, the peroxidase reaction was visualized using an enhanced chemiluminescent substrate (Santa Cruz Biotechnology).

\section{ELISA}

A sandwich ELISA assay was used to measure the amount of T $\beta$ RII-FC fusion protein in the culture supernatants of transfected cells and of parental MCF-7 cells. After a 24-h transfection, the cells were washed with PBS and incubated in serumfree medium for an additional $48 \mathrm{~h}$. The culture supernatants were then collected in siliconized microcentrifuge tubes and stored at $-80^{\circ} \mathrm{C}$ until analysis for T $\beta$ RII-Fc levels by ELISA. In brief, a 96-well plate was coated at $4{ }^{\circ} \mathrm{C}$ overnight with goat anti-human IgG (25 $\mathrm{gg} / \mathrm{mL}$, Pierce) in $50 \mathrm{mmol} / \mathrm{L}$ carbonate buffer and rinsed three times with PBST. The wells were then blocked with $1 \%$ BSA $\left(37^{\circ} \mathrm{C}\right.$ for $2 \mathrm{~h}$ ) and washed with PBST three times. Meanwhile, the culture supernatants of the tested cells were centrifuged for $5 \mathrm{~min}$ at $3500 \times \mathrm{g}$ in order to eliminate cell debris. These supernatants $(100 \mu \mathrm{L} /$ well $)$ were added to the wells and incubated for $1 \mathrm{~h}$ at $37^{\circ} \mathrm{C}$. The wells were then washed five times with PBST and incubated for $1 \mathrm{~h}$ at $37{ }^{\circ} \mathrm{C}$ with 1:3000 horseradish peroxidase-conjugated antihuman IgG (Zhongshan Biotech, Beijing, China). After being washed, the wells were incubated for 15 min with $100 \mu \mathrm{L}$ of horseradish peroxidase substrate solution. The reaction was stopped with $\mathrm{H}_{2} \mathrm{SO}_{4}$ and the absorbance was measured at $492 \mathrm{~nm}$. Finally, the relative concentration of T $\beta$ RII-Fc in the culture supernatants was determined based on a standard curve generated by known amounts of human IgG.

\section{Real-time PCR}

The tested cells were collected and reverse transcription was carried out as described above. The cDNAs were then used for real-time PCR, using SYBR green for the detection of the PCR products. The primers for CXCR4 amplification were 5'-GAACCCTGTTTCCGTGAAGA-3' and 5'-CTTGTCCGTCATGCTTCTCA-3'. Samples were incubated at $96{ }^{\circ} \mathrm{C}$ for $3 \mathrm{~min}$, followed by 40 complete cycles $\left(96^{\circ} \mathrm{C}\right.$ for 1 min, $56{ }^{\circ} \mathrm{C}$ for $1 \mathrm{~min}$, and $72{ }^{\circ} \mathrm{C}$ for $1 \mathrm{~min}$ ), and a final exten- 
sion step was performed at $72{ }^{\circ} \mathrm{C}$ for $3 \mathrm{~min}$. Relative quantification of gene expression was analyzed by the $2^{-\Delta \Delta \mathrm{Ct}}$ method with $\beta$-actin as the endogenous control ${ }^{[28]}$.

\section{Flow cytometry analysis}

The tested cells were collected and preincubated with human IgG ( $1 \mu \mathrm{g} / 10^{5}$ cells) for $15 \mathrm{~min}$ at room temperature. The cells were then incubated with $10 \mu \mathrm{L}$ of allophycocyanin (APC)conjugated mouse anti-human CXCR4 monoclonal antibody (R\&D Systems) for $30 \mathrm{~min}$ at $4{ }^{\circ} \mathrm{C}$. After this incubation, unbound antibodies were removed by washing with PBS, and the cells were resuspended in $200 \mu \mathrm{L}$ PBS buffer for analysis by flow cytometry (Becton-Dickison FACScalibur).

\section{Chemotaxis assays}

Chemotaxis assays were performed using 24-well transwell plates (8- $\mu \mathrm{m}$ pores; Corning Inc). Briefly, upper and lower transwell chambers were separated by a filter precoated with fibronectin at $4{ }^{\circ} \mathrm{C}$ overnight. Then, tested cells $\left(2 \times 10^{5}\right.$ in $100 \mu \mathrm{L}$ DMEM containing $1 \mathrm{mg} / \mathrm{mL}$ BSA) were loaded into the upper chamber, while the lower chamber was filled with $600 \mu \mathrm{L}$ of serum-free medium with or without SDF-1a (12.5 $\mathrm{ng} / \mathrm{mL}$, Upstate). After the plates were incubated in $5 \% \mathrm{CO}_{2}$ at $37^{\circ} \mathrm{C}$ for $5 \mathrm{~h}$, the cells on the upper surface were wiped off with a cotton swab, and the filters were washed with PBS, fixed in $100 \%$ methanol and stained with crystal violet. Next, the number of cells on the lower side was counted in five highpower fields $(\times 200)$ per filter. The chemotaxis index was calculated as a ratio between the number of cells migrated toward SDF-1a and the number of cells migrated in the absence of SDF-1a.

\section{Statistical analysis}

All experiments were performed at least three times, and the results shown are from representative experiments. All data are expressed as means \pm standard deviation. Statistical significance was analyzed by Student's unpaired $t$-test for two groups and two-way analysis of variance (ANOVA), followed by the Newman-Keuls Student test for multiple groups, with the significance level set at $P<0.05$.

\section{Results}

TGF- $\beta 1$ treatment increased CXCR4 expression in MCF-7 cells

TGF- $\beta 1$ upregulates CXCR4 expression on dendritic cells, eosinophils, T cells, macrophages and melanoma cells ${ }^{[17-22]}$. To investigate the effect of TGF- $\beta 1$ on breast cancer cells, the human breast cancer cell line MCF-7 was treated with rhTGF- $\beta 1$ at concentrations of 0 (control), 1, 10, $100 \mathrm{ng} / \mathrm{mL}$ for $48 \mathrm{~h}$. Next, total RNA was isolated for real-time PCR analysis of CXCR4 mRNA expression. TGF- $\beta 1$ treatment, as shown in Figure 1A, resulted in a significant increase in CXCR4 mRNA expression in MCF-7 cells. CXCR4 mRNA increased approximately 6-fold (TGF- $\beta 1,1 \mathrm{ng} / \mathrm{mL}$ ), 6-fold (TGF- $\beta 1,10$ $\mathrm{ng} / \mathrm{mL}$ ), and 10-fold (TGF- $\beta 1,100 \mathrm{ng} / \mathrm{mL}$ ) compared with the control group. Flow cytometric analysis also demonstrated that CXCR4 expression was increased on the surface of these
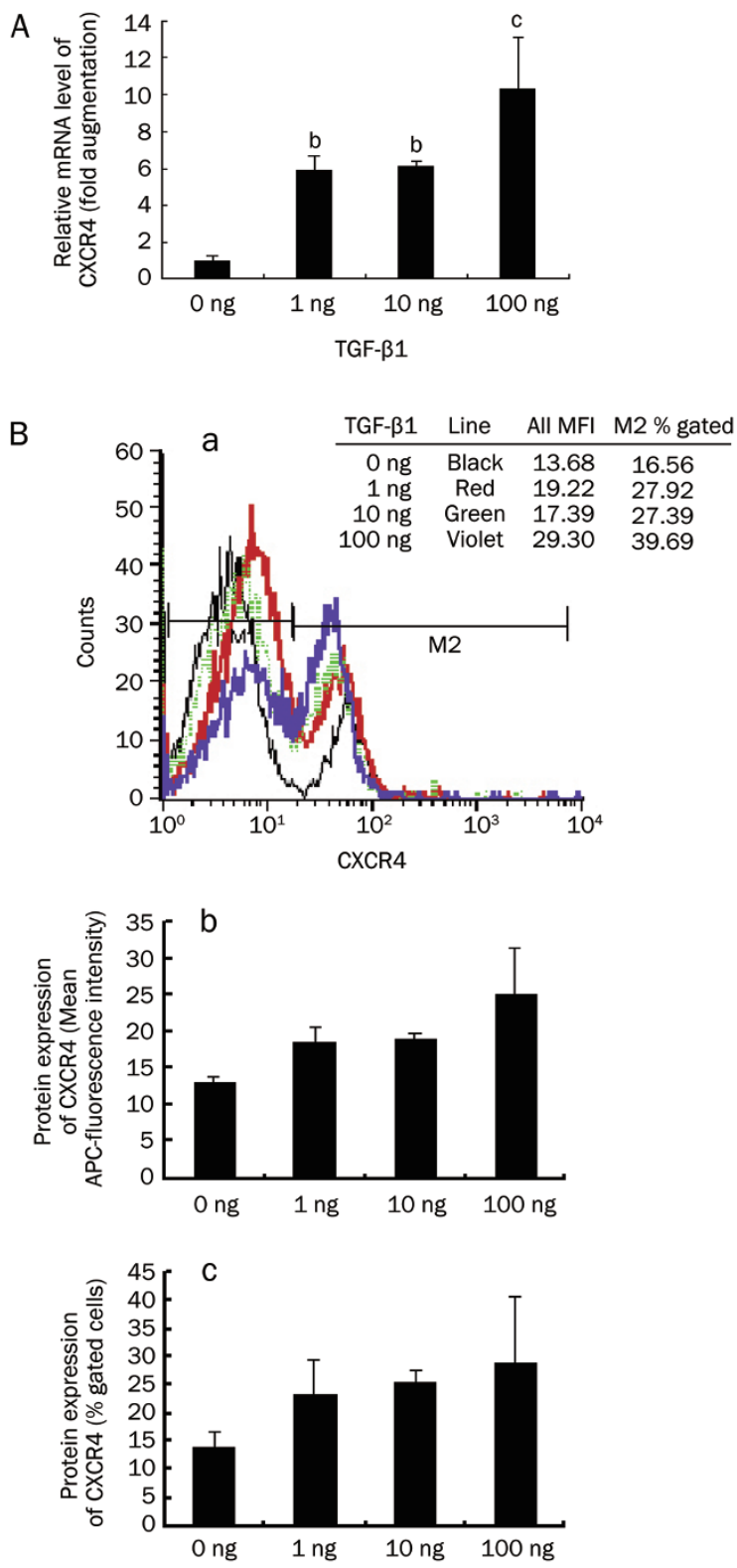

Figure 1. Upregulation of CXCR4 expression in TGF- $\beta 1$-treated MCF-7 cells. MCF-7 cells were treated with rhTGF- $\beta 1$ at the concentrations of 0 (control), 1, 10, $100 \mathrm{ng} / \mathrm{mL}$ for $48 \mathrm{~h}$. (A) CXCR4 mRNA expression was assessed by real-time PCR in MCF-7 cells treated with TGF- $\beta 1$ or not. Results are expressed as mean \pm SD for three independent experiments $(n=3)$. Statistical significance was determined by ANOVA followed by NewmanKeuls-Student's $t$ test. ${ }^{b} P<0.05,{ }^{c} P<0.01$ vs control. (B) CXCR4 protein expression on these MCF-7 cells was determined by flow cytometry using monoclonal anti-CXCR4 conjugated with APC. CXCR4 surface expression was higher on the treated cells than on the control cells. $[\mathrm{B}(\mathrm{a})]$, the data presented here represent a typical experiment. $[B(b)]$ represents CXCR4 surface expression, measured as mean fluorescence intensity (MFI), on these cells, and $[\mathrm{B}(\mathrm{C})]$ is the result expressed as the percentage of gated cells. In B, each bar represents the mean of 3 independent experiments.

treated cells (Figure 1B). Thus, the expression of CXCR4 mRNA and protein was increased in MCF-7 cells after treatment with TGF- $\beta 1$. 
TGF- $\beta 1$ treatment enhanced the chemotactic response of MCF-7 cells to SDF-1 $\alpha$

To determine whether TGF- $\beta 1$-induced upregulation of CXCR4 expression has a corresponding biological effect, we examined the chemotactic response of MCF-7 cells to SDF-1a using a chemotaxis assay. MCF-7 cells were treated with or without TGF- $\beta 1$ ( $1 \mathrm{ng} / \mathrm{mL}$ ) for $48 \mathrm{~h}$ and then subjected to the chemotaxis assay described above. Figure 2 shows that TGF- $\beta 1$ treatment was associated with a 2.5 -fold increase in the chemotactic response to SDF-1a $(P<0.01)$. These results suggest that TGF- $\beta 1$ treatment not only led to an upregulation of CXCR4 expression in MCF-7 cells but also increased the chemotactic response to SDF-1a.

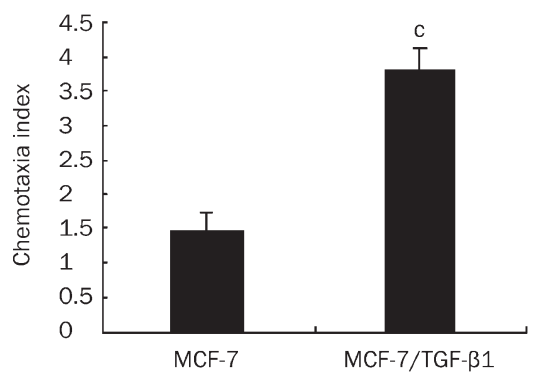

Figure 2. The chemotactic response of TGF- $\beta 1$-treated MCF-7 cells to SDF- $1 \alpha$. The chemotaxis assay was performed as described in materials and methods. The results are presented as the chemotaxis index, which is a ratio between the number of cells migrated toward SDF-1 $\alpha$ and the number of cells migrated in the absence of SDF-1 $\alpha$. Mean \pm SEM. Representative data are shown from one of three experiments. The chemotaxis data were analyzed using Student's unpaired $t$-test. ${ }^{c} P<0.01$ vs MCF-7 cells.

\section{A T $\beta$ RII-Fc fusion protein was secreted by MCF-7 cells transfected with pIRES2-EGFP-T $\beta R I I-F c$}

T $\beta$ RII-Fc, a fusion protein composed of the extracellular domain of TGF- $\beta$ type II receptor and the constant region of IgG1, has been found to inhibit the metastasis of mammary tumor cells ${ }^{[7]}$. To obtain T $\beta$ RII-Fc fusion protein, we constructed a bicistronic plasmid, pIRES2-EGFP-T $\beta$ RII-Fc, which expressed T $\beta$ RII-Fc and EGFP separately. This construct was confirmed by restriction digest analysis and DNA sequencing (data not shown). MCF-7 cells were transfected with either pIRES2-EGFP-T $\beta$ RII-Fc or pIRES2-EGFP (control). Forty-eight hours later, total RNA, cell lysates and culture supernatants were examined by RT-PCR, Western blotting, and ELISA, respectively. The RT-PCR products were analyzed by electrophoresis in a 1.5\% agarose gel. A specific band of $1200 \mathrm{bp}$ was observed in the T $\beta$ RII-Fc transfected MCF-7 cells, but not in the vector control or parental cells (Figure 3A). This result confirmed that T $\beta$ RII-Fc mRNA was expressed in pIRES2EGFP-T $\beta$ RII-Fc transfected cells. By Western blotting, the recombinant T $\beta$ RII-Fc was detected as a strong $41-\mathrm{kDa}$ band, using anti-human IgG antibody, in T $\beta$ RII-Fc transfected MCF-7 cells, but not in vector control or parental cells (Figure
A
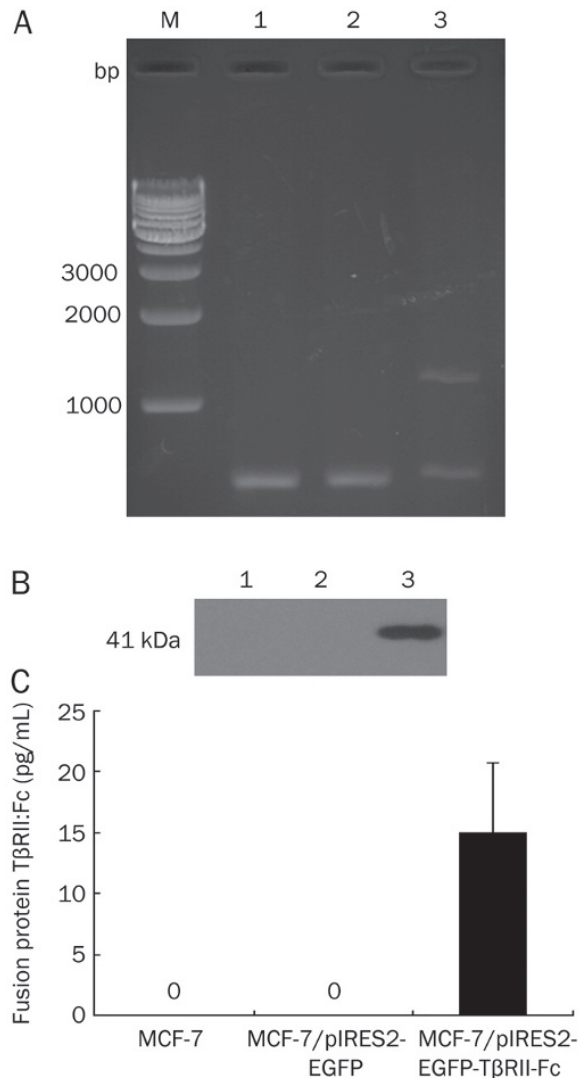

Figure 3. Expression of T $\beta R I I: F c$ fusion protein in T $\beta R I I-F c$ transfected MCF-7 cells. MCF-7 cells were transfected with pIRES2-EGFP-T $\beta R I I-F C$ or pIRES2-EGFP (control) for $48 \mathrm{~h}$. (A) T $\beta R$ II-Fc fusion gene expression was analyzed by RT-PCR and agarose gel electrophoresis. A specific $1200 \mathrm{bp}$ band was observed in TRRII-Fc transfected MCF-7 cells (lane 3 ), but not in the vector control (lane 2) or parental cells (lane 1), and $\beta$-actin mRNA was used as internal control. (B) Total cell lysates were analyzed by Western blotting for the presence of fusion protein, T $\beta R$ II:Fc. A strong $41 \mathrm{kDa}$ band was detected in TBRII-Fc transfected MCF-7 cells (lane 3), but not in vector control (lane 2) or parental cells (lane 1). (C) An ELISA assay was used to measure the T $\beta R$ RII:Fc fusion protein in the culture supernatants of the tested cells. Each bar represents the mean of six independent experiments.

3B). The result of the ELISA, illustrated in Figure 3C, revealed that the T $\beta R I I-F_{c}$ fusion protein was detected in the culture supernatants of T $\beta$ RII-Fc transfected cells, while it was undetectable in control groups. These results suggested that the T $\beta$ RII-Fc fusion protein was produced and secreted by MCF-7 cells transfected with pIRES2-EGFP-T $\beta$ RII-Fc.

CXCR4 mRNA and protein expression were reduced in T $\beta$ RII-Fc transfected MCF-7 cells

To investigate whether CXCR4 expression is regulated by fusion protein T $\beta$ RII-Fc in transfected MCF-7 cells, CXCR4 expression at the mRNA and protein levels was measured in these cells. The result of real time quantitative PCR revealed that the level of CXCR4 mRNA expression was reduced by sixty percent in the T $\beta R I I-F c$ transfected cells compared with 
that in the control cells (Figure 4A). In addition, CXCR4 expression was also reduced on the surface of the T $\beta$ RII-FCtransfected cells as measured by flow cytometry (Figure 4B). The transfected MCF-7 cells in FCM analysis were classified into four types according to the expression levels of CXCR4 and EGFP: CXCR4 ${ }^{-} \mathrm{EGFP}^{-}, \mathrm{CXCR}^{-} \mathrm{EGFP}^{+}, \mathrm{CXCR}^{+} \mathrm{EGFP}^{-}$and $\mathrm{CXCR}^{+} \mathrm{EGFP}^{+}$. In the T $\beta \mathrm{RII}-\mathrm{Fc}$ transfected cells, CXCR4 expression was decreased on both $\mathrm{CXCR} 4^{+} \mathrm{EGFP}^{-}$and $\mathrm{CXCR}^{+} \mathrm{EGFP}^{+}$cells compared with those of corresponding pIRES2-EGFP transfected MCF-7 cells (Figure 4Ba-c). T $\beta$ RII-FC may reduce $\mathrm{CXCR} 4$ protein expression in both autocrine and paracrine fashions. Therefore, the T $\beta$ RII-Fc transfected MCF-7 cells demonstrated a decrease in CXCR4 expression at both the mRNA and the protein levels.

The SDF-1 $\alpha$-induced chemotactic response was inhibited in the T $\beta$ RII-Fc transfected MCF-7 cells

To further investigate the effect on the chemotactic response, transfected MCF-7 cells were subjected to chemotaxis assays in response to SDF-1a, as described above. The results in Figure 5 indicated that the T $\beta$ RII-Fc transfected cells exhibited lower chemotactic activity than control cells $(P<0.01)$. This suggests
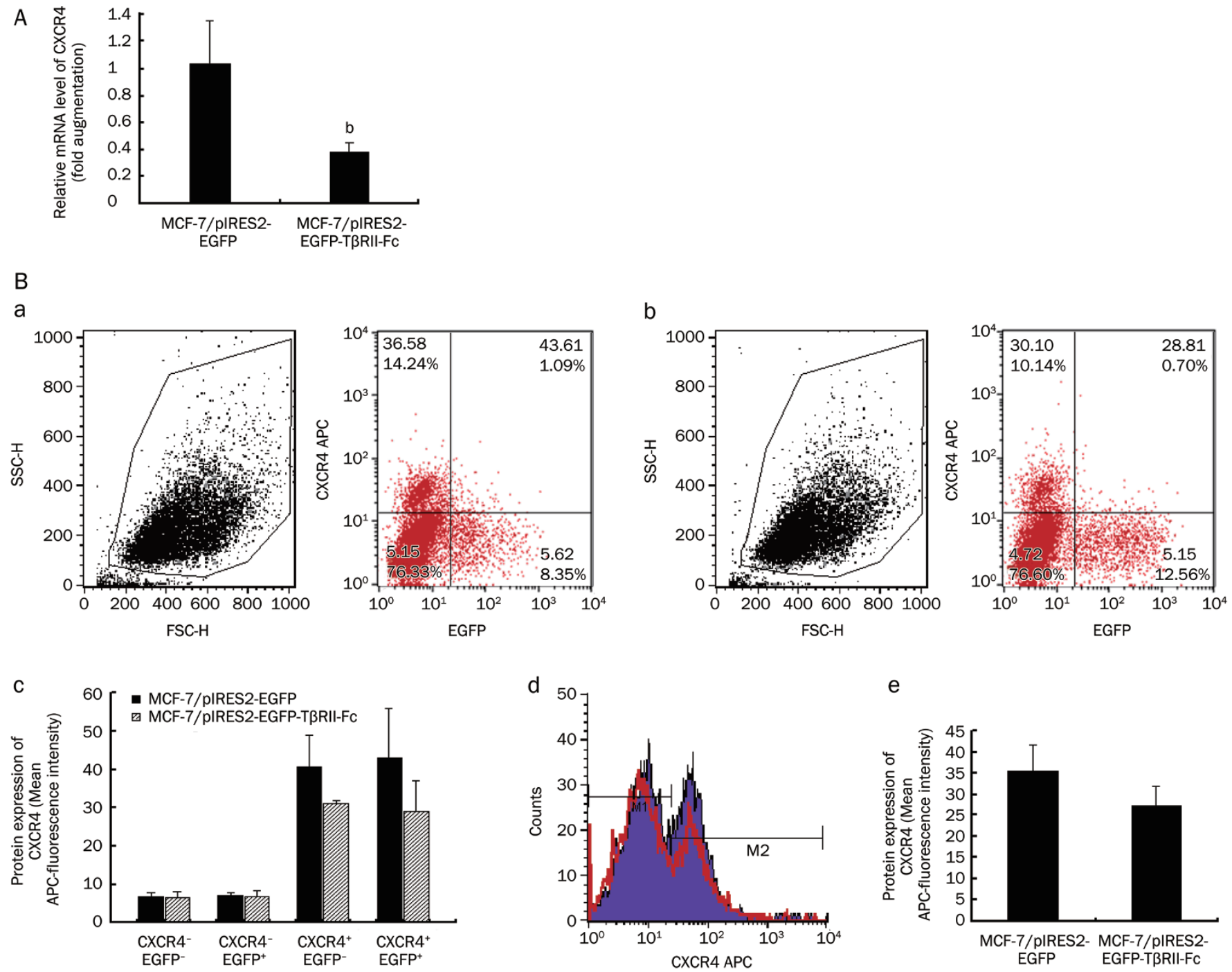

Figure 4. Downregulation of CXCR4 expression in TßRII-Fc transfected MCF-7 cells. MCF-7 cells were transfected with pIRES2-EGFP-TßRII-Fc or pIRES2EGFP (control) for $48 \mathrm{~h}$, and then these cells were harvested and examined by quantitative RT-PCR and flow cytometry, respectively. (A) The result of quantitative RT-PCR revealed that CXCR4 mRNA expression was reduced by $60 \%$ in TßRII-Fc transfected cells as compared with that in the control cells. Data are expressed as mean \pm SEM of three separate experiments. Statistical significance was assessed by using Student's unpaired $t$-test. ${ }^{b} P<0.05$. (B) The flow cytometric analysis showed that the level of CXCR4 expression in pIRES2-EGFP-TßRII-Fc transfected MCF-7 cells [B(b)] was lower than that in pIRES2-EGFP transfected MCF-7 cells [B(a)]. The transfected MCF-7 cells were classified into four types according to the expression levels of CXCR4 (ie the relative level of APC fluorescence) and EGFP: CXCR4-EGFP, CXCR4-EGFP ${ }^{+}$, CXCR4 ${ }^{+}$EGFP and CXCR4 ${ }^{+}$EGFP'. In T $\beta R I I-F c$ transfected cells, CXCR4 expression was decreased on both CXCR4 ${ }^{+}$EGFP and CXCR4 ${ }^{+}$EGFP ${ }^{+}$cells, compared with those of corresponding pIRES2-EGFP transfected MCF-7 cells $[B(c)]$. $[B(d)]$ represents the difference of CXCR4 expression between TßRII-Fc transfected MCF-7 cells (red line) and control cells. And the bar graph [B(e)] shows the MFI of CXCR4 expression on these MCF-7 cells. The bar graph summarizes three independent experiments. 


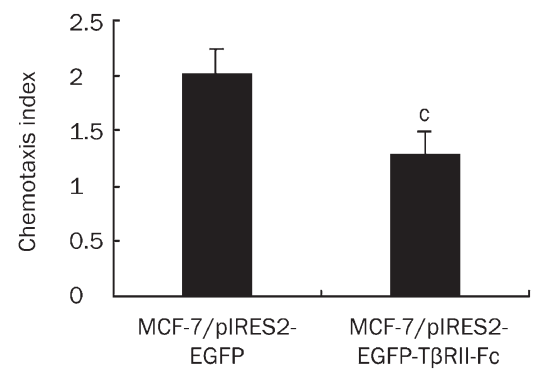

Figure 5. A reduction of the SDF-1 $\alpha$-induced chemotactic response in T $\beta$ RII-Fc transfected MCF-7 cells. The transfected MCF-7 cells were subjected to chemotaxis assays as described above. The results are presented as the chemotaxis index. Representative data are shown from one of three experiments, and the chemotaxis data were analyzed using Student's unpaired $t$-test. ${ }^{c} P<0.01$.

that the chemotactic response to SDF-1a was reduced in the T $\beta$ RII-Fc transfected MCF-7 cells.

\section{Discussion}

Although metastasis is the main cause of death in breast cancer patients, the molecular mechanism of breast cancer metastasis remains largely unknown. Recent studies have revealed that both TGF- $\beta 1$ and CXC chemokine receptor 4 (CXCR4) are two major metastatic factors in human breast cancers ${ }^{[1,2]}$. In this study, we found that a link exists between TGF- $\beta 1$ and CXCR4 expression in human breast cancer MCF-7 cells. To our knowledge, this is the first study on TGF- $\beta 1$-mediated CXCR4 upregulation in human breast cancer cells.

More and more studies suggest that the SDF-1a/CXCR4 system plays a key role in the progression of breast cancer, including angiogenesis, tumor growth and invasion ${ }^{[29]}$. Intriguingly, this system has been reported to be involved in promoting organ-specific metastasis of breast cancer cells ${ }^{[2]}$. Thus, CXCR4-expressing breast cancer cells could migrate to other organs where SDF-1a is secreted, such as the bone marrow and lymph nodes, and this may be one of the molecular mechanisms to organ preference of breast cancer cell metastasis $^{[2,5]}$.

CXCR4 expression can be regulated by several cytokines, such as interleukin (IL)-4, IL-10 ${ }^{[30]}, \mathrm{IL}^{-7^{[31]}}$, TNF-a ${ }^{[32]}$, G-CSF ${ }^{[33]}$, TGF- $\beta 1^{[17-22]}$ and so on. Among these cytokines, TGF- $\beta 1$ is considered a key factor in promoting breast cancer metastasis $^{[1]}$. For example, the overexpression of active TGF- $\beta 1$ (MMTV-TGF- $\beta 1^{\mathrm{s} 223 / 225}$ ) was found to promote lung metastasis in a mouse mammary carcinoma model ${ }^{[12]}$. Conversely, blockade of TGF- $\beta$ signaling via a dominant-negative mutant of the TGF- $\beta$ type II receptor (T $\beta$ RII-cyt) led to the inhibition of metastasis of the human breast cancer cell line MDA-MB-231 to bone ${ }^{[13]}$. We therefore wanted to explore the effect of TGF- $\beta 1$ on the regulation of CXCR4 expression in breast cancer cells. In this work, we found that treatment of the breast cancer cell line MCF-7 with TGF- $\beta 1$ resulted in an upregulation of CXCR4 expression at both mRNA and protein levels (Figure 1). Furthermore, these treated cells dem- onstrated an increase in the chemotactic response to SDF-1a (Figure 2). These findings indicate that TGF- $\beta 1$ had a positive effect on the regulation of CXCR4 mRNA and protein expression in MCF-7 cells and enhanced their chemotactic activity in response to SDF-1a.

TGF- $\beta 1$ secretion was increased in stromal and tumor cells, including in breast cancer $^{[34]}$. Increased expression of TGF- $\beta 1$, for example, was detected in MDA-MB231, MCF-7 and MDAMB436 ${ }^{[14,35]}$. We also investigated TGF- $\beta 1 \mathrm{mRNA}$ and protein expression in MCF-7 cells using the RT-PCR and ELISA assay, respectively. TGF- $\beta 1 \mathrm{mRNA}$ was detected in MCF-7 cells and TGF- $\beta 1$ protein was secreted into the culture supernatant (data not shown), consistent with previously published data.

Several approaches to block TGF- $\beta$ activity in breast cancer cells have been developed, including soluble T $\beta \mathrm{RIII}^{[14]}$, soluble $\mathrm{T} \beta \mathrm{RII}^{[15]}$, dominant-negative T $\beta \mathrm{RII}^{[24]}$, mutant TGF- $\beta$ receptor II (mutant T $\beta R I I)^{[36]}$, and so on. In this paper, we constructed a recombinant vector, pIRES2-EGFP-T $\beta$ RII-Fc, which was confirmed by restriction digest analysis and DNA sequencing (data not shown). MCF-7 cells were then transiently transfected with the recombinant vector. A fusion protein (approximately $41 \mathrm{kDa}$ ), named T $\beta$ RII-Fc, was produced and secreted into the culture supernatant of these transfected cells (Figure 3). T $\beta$ RII-Fc fusion protein, a soluble form of TGF- $\beta$ receptor II, proved to be an effective TGF- $\beta$ antagonist; more importantly, it was found to suppress lung metastasis of mammary tumor cells in MMTV-Polyomavirus middle $\mathrm{T}$ antigen transgenic mice ${ }^{[15]}$.

We wondered whether the downregulation of CXCR4 expression could be one of the mechanisms of T $\beta$ RII-Fcmediated suppression of breast cancer metastasis. To test this hypothesis, CXCR4 expression was examined at the mRNA and protein levels in transfected MCF-7 cells. These cells exhibited a decrease in CXCR4 expression at both levels (Figure 4). Moreover, this soluble protein may reduce CXCR4 protein expression in both autocrine and paracrine fashions, and their chemotactic response to SDF-1a was significantly $(P<0.01)$ reduced compared to control cells (Figure 5). These results may be due to the negative effects of fusion protein T $\beta$ RII-Fc on CXCR4 expression in breast cancer cells, which may be one reason why the blockade of TGF- $\beta 1$ signaling led to the inhibition of breast cancer metastasis.

Together, these data indicate that TGF- $\beta 1$ upregulated CXCR4 expression in MCF-7 cells, which subsequently enhanced their chemotactic response to SDF-1a. Additionally, we speculate that TGF- $\beta 1$ may also be associated with the overexpression of CXCR4 and increased metastasis of other human breast cancer cell lines, such as MDA-MB-231 and MDA-MB-435. It has been reported that both TGF- $\beta 1$ and CXCR4 are overexpressed in MDA-MB-231 cells, and blockade of TGF- $\beta 1$ activity by soluble T $\beta$ RIII resulted in the inhibition of lung metastasis of these cells ${ }^{[2,14,35]}$. Another human breast cancer cell line, MDA-MB-435, was found to express both TGF- $\beta 1$ and CXCR $4^{[37,38]}$. More importantly, the inhibition of TGF- $\beta 1$ expression using small interfering RNA led to a decrease in the migratory potential of MDA-MB-435 in 
vitro and in vivo ${ }^{[38]}$. Further studies are needed to confirm this speculation.

Based on the above findings, we conclude that the upregulation of CXCR4 expression may be involved in the role of TGF- $\beta 1$ in breast cancer metastasis. In addition, previous studies have reported that TGF- $\beta 1$ can induce the expression of parathyroid-hormone related peptide (PTHrP), connective tissue-derived growth factor (CTGF) and interleukin-11 (IL-11) in breast cancer cells. The overexpression of these proteins may contribute to breast cancer metastasis to bone ${ }^{[13,39]}$. Therefore, TGF- $\beta 1$ seems to promote metastasis through different mechanisms in breast cancer cells, and upregulation of CXCR4 expression may be one of the mechanisms of TGF- $\beta 1$-mediated enhancement of the metastatic potential of breast cancer cells.

As demonstrated in this study, CXCR4 expression was upregulated after TGF- $\beta 1$ treatment of MCF-7 cells, and these treated cells showed an increase in the chemotactic response to SDF-1a. On the other hand, MCF-7 cells were transiently transfected with pIRES2-EGFP-T $\beta$ RII-Fc, and these cells showed a reduction in CXCR4 expression as well as SDF-1ainduced chemotaxis. In summary, our results suggest that a link exists between TGF- $\beta 1$ and CXCR4 expression in MCF-7 human breast cancer cells and that this may be one of the mechanisms of the TGF- $\beta 1$-mediated enhancement of metastatic potential in breast cancer cells. In addition, our findings support the notions that (1) TGF- $\beta 1$ is an important cytokine to enhance metastasis in breast cancer cells and (2) blockade of TGF- $\beta 1$ signaling can suppress breast cancer metastasis. In the future, more studies will be needed to expand these investigations to other breast cancer cell lines, and it will be necessary to elucidate the molecular mechanism of TGF- $\beta 1$-mediated regulation of CXCR4 gene expression in human breast cancer cells.

\section{Acknowledgments}

We thank Prof Zuo-hua FENG for valuable discussions and advice. We also thank Dr Jun-fa XU and Bao-jun HUANG for providing the pcDNA3.1-Fc plasmid. The study was supported by the 863 program of China (№ 2006AA02Z158) and the Doctoral Fund of Ministry of Education of China (No 20060487024 and 20070487103).

\section{Author contribution}

Xiao-ping ZHAO, Yong-yao HUANG and Guan-xin SHEN designed research; Xiao-ping ZHAO, Yong-yao HUANG, Yu HUANG, Ping LEI, Ji-lin PENG, Sha WU, Min WANG, Wen-han LI and Hui-fen ZHU performed research; Xiao-ping ZHAO and Yu HUANG contributed new analytical tools and reagents, as well as analyzed data; Xiao-ping $\mathrm{ZHAO}$ wrote the paper.

\section{References}

1 Derynck R, Akhurst RJ, Balmain A. TGF- $\beta$ signaling in tumor suppression and cancer progression. Nat Genet 2001; 29: 117-29.

2 Müller A, Homey B, Soto H, Ge N, Catron D, Buchanan ME, et al. Involvement of chemokine receptors in breast cancer metastasis.
Nature 2001; 410: 50-6.

3 Bleul CC, Farzan M, Choe H, Parolin C, Clark-Lewis I, Sodroski J, et al. The lymphocyte chemoattractant SDF-1 is a ligand for LESTR/fusin and blocks HIV-1 entry. Nature 1996; 382: 829-33.

4 Zlotnik A, Yoshie 0. Chemokines: a new classification system and their role in immunity. Immunity 2000; 12: 121-7.

5 Balkwill F. Cancer and the chemokine network. Nat Rev Cancer 2004; 4: 540-50.

6 Shirozu M, Nakano T, Inazawa J, Tashiro K, Tada H, Shinohara T, et al. Structure and chromosomal localization of the human stromal cellderived factor 1 (SDF1) gene. Genomics 1995; 28: 495-500.

7 Siegel PM, Massagué J. Cytostatic and apoptotic actions of TGF- $\beta$ in homeostasis and cancer. Nat Rev Cancer 2003; 3: 807-20.

8 Massague J. TGF-beta signal transduction. Annu Rev Biochem 1998; 67: 753-91.

9. Salomon DS, Zwiebel JA, Bano M, Losonczy I, Fehnel P, Kidwell WR. Presence of transforming growth factors in human breast cancer cells. Cancer Res 1984; 44: 4069-77.

10 Gorsch SM, Memoli VA, Stukel TA, Gold LI, Arrick BA. Immunohistochemical staining for transforming growth factor $\beta 1$ associates with disease progression in human breast cancer. Cancer Res 1992; 52: 6949-52.

11 Dalal BI, Keown PA, Greenberg AH. Immunocytochemical localization of secreted transforming growth factor- $\beta 1$ to the advancing edges of primary tumors and to lymph node metastases of human mammary carcinoma. Am J Pathol 1993; 143: 381-9.

12 Muraoka RS, Koh Y, Roebuck LR, Sanders ME, Brantley-Sieders D, Gorska $\mathrm{AE}$, et al. Increased malignancy of Neu-induced mammary tumors overexpressing active transforming growth factor $\beta 1$. Mol Cell Biol 2003; 23: 8691-703.

13 Yin JJ, Selander K, Chirgwin JM, Dallas M, Grubbs BG, Wieser R. TGF- $\beta$ signaling blockade inhibits PTHrP secretion by breast cancer cells and bone metastases development. J Clin Invest 1999; 103: 197-206.

14 Bandyopadhyay A, Zhu Y, Cibull ML, Bao L, Chen C, Sun L. A soluble transforming growth factor $\beta$ type III receptor suppresses tumorigenicity and metastasis of human breast cancer MDA-MB-231 cells. Cancer Res 1999; 59: 5041-6.

15 Muraoka RS, Dumont N, Ritter CA, Dugger TC, Brantley DM, Chen J, et al. Blockade of TGF- $\beta$ inhibits mammary tumor cell viability, migration, and metastases. J Clin Invest 2002; 109: 1551-9.

16 Yang YA, Dukhanina O, Tang B, Mamura M, Letterio JJ, MacGregor J, et al. Lifetime exposure to a soluble TGF- $\beta$ antagonist protects mice against metastasis without adverse side effects. J Clin Invest 2002; 109: 1607-15.

17 Zoeteweij JP, Golding H, Mostowski H, Blauvelt A. Cytokines regulate expression and function of the HIV coreceptor CXCR4 on human mature dendritic cells. J Immunol 1998; 161: 3219-23.

18 Sato K, Kawasaki H, Nagayama H, Enomoto M, Morimoto C, Tadokoro K. TGF- $\beta 1$ reciprocally controls chemotaxis of human peripheral blood monocyte-derived dendritic cells via chemokine receptors. J Immunol 2000; 164: 2285-95.

19 Nagase H, Miyamasu M, Yamaguchi M, Fujisawa T, Ohta K, Yamamoto $\mathrm{K}$, et al. Expression of CXCR4 in eosinophils: functional analyses and cytokine-mediated regulation. J Immunol 2000; 164: 5935-43.

20 Buckley CD, Amft N, Bradfield PF, Pilling D, Ross E, ArenzanaSeisdedos $\mathrm{F}$, et al. Persistent induction of the chemokine receptor CXCR4 by TGF- $\beta 1$ on synovial T cells contributes to their accumulation within the rheumatoid synovium. J Immunol 2000; 165: 3423-9.

21 Chen S, Tuttle DL, Oshier JT, Knot HJ, Streit WJ, Goodenow MM, et al. Transforming growth factor- $\beta 1$ increases CXCR4 expression, stromal- 
derived factor- $1 \alpha$-stimulated signalling and human immunodeficiency virus-1 entry in human monocyte-derived macrophages. Immunology 2005; 114: 565-74.

22 Javelaud D, Mohammad KS, McKenna CR, Fournier P, Luciani F, Niewolna $\mathrm{M}$, et al. Stable overexpression of Smad7 in human melanoma cells impairs bone metastasis. Cancer Res 2007; 67: 2317-24.

23 Zajchowski D, Band V, Pauzie N, Tager A, Stampfer M, Sager R. Expression of growth factors and oncogenes in normal and tumorderived human mammary epithelial cells. Cancer Res 1988; 48: 7041-7.

24 Koli KM, Ramsey TT, Ko Y, Dugger TC, Brattain MG, Arteaga CL, et al. Blockade of transforming growth factor- $\beta$ signaling does not abrogate antiestrogen-induced growth inhibition of human breast carcinoma cells. J Biol Chem 1997; 272: 8296-302.

$25 \mathrm{Yu}$ YH, Yang DF, Xie LK, et al. Construction and expression of the eukaryotic expression vector containing truncated type II human transforming growth factor-beta receptor. Acta Med Univ Sci Tech Huazhong 2007; 36: 130-3.

26 Yin H, Huang BJ, Yang H, Huang YF, Xiong P, Zheng F, et al. Pretreatment with soluble ST2 reduces warm hepatic ischemia/reperfusion injury. Biochem Biophys Res Commun 2006; 351: 940-6.

27 Peng JL, Wu S, Zhao XP, Wang M, Li WH, Shen X, et al. Downregulation of transferrin receptor surface expression by intracellular antibody. Biochem Biophys Res Commun 2007; 354: 864-71.

28 Livak KJ, Schmittgen TD. Analysis of relative gene expression data using real-time quantitative PCR and the $2^{-\Delta \Delta \mathrm{Ct}}$ method. Methods 2001; 25: 402-8.

29 Orimo A, Gupta PB, Sgroi DC, Arenzana-Seisdedos F, Delaunay T, Naeem R, et al. Stromal fibroblasts present in invasive human breast carcinomas promote tumor growth and angiogenesis through elevated SDF-1/CXCL12 secretion. Cell 2005; 121: 335-48.

30 Jinquan T, Quan S, Jacobi HH, Madsen HO, Glue C, Skov PS, et al. CXC chemokine receptor 4 expression and stromal cell-derived factor-1 alpha-induced chemotaxis in $\mathrm{CD} 4^{+} \mathrm{T}$ lymphocytes are regulated by interleukin-4 and interleukin-10. Immunology 2000; 99: 402-10.

31 Schmitt N, Chêne L, Boutolleau D, Nugeyre MT, Guillemard E, Versmisse $\mathrm{P}$, et al. Positive regulation of CXCR4 expression and signaling by interleukin-7 in CD4 mature thymocytes correlates with their capacity to favor human immunodeficiency X4 virus replication. J Virol 2003; 77: 5784-93.

32 Han Y, Wang J, He T, Ransohoff RM. TNF-alpha down-regulates CXCR4 expression in primary murine astrocytes. Brain Res 2001; 888: 1-10.

33 Kim HK, De La Luz Sierra M, Williams CK, Gulino AV, Tosato G. G-CSF down-regulation of CXCR4 expression identified as a mechanism for mobilization of myeloid cells. Blood 2006; 108: 812-20.

34 Dumont N, Arteaga CL. Transforming growth factor- $\beta$ and breast cancer: Tumor promoting effects of transforming growth factor- $\beta$. Breast Cancer Res 2000; 2: 125-32.

35 Derynck R, Goeddel DV, Ullrich A, Gutterman JU, Williams RD, Bringman TS, et al. Synthesis of messenger RNAs for transforming growth factors $\alpha$ and $\beta$ and the epidermal growth factor receptor by human tumors. Cancer Res 1987; 47: 707-12.

36 Dumont N, Bakin AV, Arteaga CL. Autocrine transforming growth factor- $\beta$ signaling mediates Smad-independent motility in human cancer cells. J Biol Chem 2003; 278: 3275-85.

37 Lechertier T, Berard M, Vassy R, Herve MA, Crepin M. Transendothelial migration of two metastatic breast carcinoma cells depend on the SDF-1 $\alpha-C X C R 4$ complexes. Anticancer Res 2004; 24: 4011-8.

38 Moore LD, Isayeva T, Siegal GP, Ponnazhagan S. Silencing of transforming growth factor- $\beta 1$ in situ by RNA interference for breast cancer: implications for proliferation and migration in vitro and metastasis in vivo. Clin Cancer Res 2008; 14: 4961-70.

39 Kang Y, Siegel PM, Shu W, Drobnjak M, Kakonen SM, Cordón-Cardo $\mathrm{C}$, et al. A multigenic program mediating breast cancer metastasis to bone. Cancer Cell 2003; 3: 537-49. 